DOI: $10.1515 / \mathrm{rpp}-2016-0044$

Doctor of Pedagogical Sciences, Full Professor, OLENA SEMENOG

A. S. Makarenko Sumy State Pedagogical University, Ukraine Address: 87 Romenska St., Sumy, 40009, Ukraine

E-mail: olenasemenog@gmail.com

\title{
FORMING PROFESSIONAL MOBILITY IN THE PROCESS OF FUTURE MASTER PHILOLOGISTS' TRAINING IN UKRAINE AND ABROAD
}

\begin{abstract}
On the basis of scientific research, the experience of higher education institutions in Ukraine and abroad (the USA, the Swiss Confederation) concerning the forming of future philologists' professional mobility in the process of Master training has been generalized. It has been overviewed, that professional mobility is an essential indicator of the professional and social maturity of a worker. It has been found out that the content of the Master training has to ensure the forming of such features of professional mobility: openness and creativity, which are expressed in susceptibility to new and rejection from stereotypes, in the creative attitude to the profession; commitment to occupy the new activities; an ability for quick adaptation to changing conditions of professional activity; communication. It has been proved, that the forming of specialists' professional mobility in philology in the process of Master training is more productive when it is based on the ground of values and consistent with professional competence. Having analysed the experience of the aforementioned universities, state standards of competence training of Master philologists have been developed. They are oriented to innovation in professional activities. As a result of fundamental scientific training, which is undertaken during problem lectures, seminars, discussions, scientific workshops, there is a specialist with high social maturity, professional liability, with philological and pedagogical knowledge, words and style, reading culture, compression, editing, translation, building a new high-quality text, communicative culture, with the willingness to use the experience in various fields of teaching, scientific research, administrative innovation.

Key words: mobility, professional mobility, academic mobility, training of Master philologists, interdisciplinary course, workshop, universities of Ukraine, the USA, the Swiss Confederation.
\end{abstract}

\section{INTRODUCTION}

A specialist, who is eager to "innovative type of professional activity" (Національна академія педагогічних наук України, 2016), with an active life position, with a deep knowledge of professional duty and social responsibility, a commitment to flexible collaboration and adaptability in difficult conditions of professional and social reality, so a professionally mobile and competitive person is more and more expected in every sector of the economy, establishment or institution. Professional mobility is recognised as a natural and indispensable measure of professional and social maturity of a worker.

One of the most required and the most determining factor of "Ukraine transition to the innovative type of progress and knowledge society" (Національна академія педагогічних наук України, 2016), a significant resource for professional mobility is a Master of higher education. According to the Law of Ukraine "On Higher Education" (2014), 
education for receiving Master's degree involves the obtaining of deep theoretical and practical knowledge and skills in a chosen speciality.

According to the requirements of the National Qualifications Framework and the project "Tuning Educational Structures in Europe" it has been determined that Master must be aware of the latest methods and technologies, theories and their interpretation in the field of subject, critically monitor and interpret theory and practice development, own methods of independent research and be able to explain the results on scientific level, must be able to make an original contribution to a specific subject area, demonstrate originality and creativity in scientific research or activity (Національна академія педагогічних наук України, 2016).

In particular, the professional activity of Masters of Philological Sciences requires the possession of fundamental philological, pedagogical, psychological knowledge, words and style, reading culture, compression, editing, translation, building a new high-quality text, communicative culture, with the willingness to use the experience in various fields of teaching, research, management innovation.

Scientific studies are valuable for training Masters of Philological Sciences in higher education institutions both in Ukraine and abroad, particularly in the United States, the Swiss Confederation. In these countries, the focus is observed on the development of the creative personality, on the career development in professional, research field, competitiveness.

THE AIM OF THE STUDY

In the article the scientific researches regarding the forming of professional mobility of future Masters in the process of Master training in philology in higher education institutions of Ukraine, the USA, the Swiss Confederation, in particular, during subjects of study, research performance have been summarised.

\section{THEORETICAL FRAMEWORK AND RESEARCH METHODS}

Questions of professional mobility, attitudes, motives, personal values in the context of professional mobility have been explored by Ukrainian scientists (I. Herasymova, L. Lukyanova, N. Nychkalo, R. Prima, L. Suschentseva and others) and by foreign scientists (P. Erickson, H. Hazenbum and others). Various aspects of Master training in the context of innovative development of higher education are dedicated to the research of V. Andrushchenko, N. Avshenyuk, N. Bidyuk, L. Hrynevych, V. Kremen, V. Lugova, A. Matvienko, N. Nychkalo, I. Zyazyun and others), questions concerning Master training, including philological education in Ukraine, the USA, Switzerland are presented in scientific papers of O. Ohiyenko, L. Puhovska, I. Sokolova, N. Zasluzhena, O. Zinovatna and others).

Among the methods, which are used in the study, we define, in particular, such methods of investigation as analysis, comparison, generalisation - to study the regulatory documents, works of native and foreign scientists, scientific and methodological information which are submitted on the websites of universities. The methodological basis of the research comprises the ideas of systematic, competence, axiological approaches for training Masters of Philological Sciences.

\section{RESULTS}

First of all it is necessary to find out the definition of "mobility". Analysis of dictionary sources shows that this word (from the Latin "mobilis") has several meanings, among which the most important for our study is "mobility" as the capacity for rapid movement, action (Нечволод, 2007); "The ability to act quickly, make decisions; ability to quickly orient themselves in different circumstances, to find the required forms of action" (Парсонс, 2000).

According to the analysis of scientific sources, the term "mobility" is an interdisciplinary and it is used by specialists of philosophy, economics, sociology, psychology, 
pedagogy. In the educational and scientific area there are such phrases as "professional mobility", "social mobility", "career mobility", "professional and educational mobility", "academic mobility" and others. In particular, social mobility is described by T. Parsons (2000), P. Sorokin (2008) as any transition of individual or social object (value), so that is all which is created or modified by human activity, from one position to another, social movements, movement between different socioeconomic positions, changes in social roles; ability to find adequate ways to solve unexpected problems and perform unusual tasks; the ability of the individual to adapt and transform the social environment; ability to quickly establish personal, cultural and business contacts in micro and macro environment.

The Professional mobility of specialist researchers (V. Bobrytska, I. Herasymova, R. Prima, L. Suschentseva et al.) is associated with such concepts as "dynamic" and "satisfaction with the profession", "compliance requirements of individual qualities of the profession". In the ground of pedagogical approach to the category of "professional mobility", noted by R. Erickson (1992), H. Ganzenboom (1989), N. Nychkalo (2007), L. Suschenceva (2011), professional educational opportunities of the future specialist were laid; it was taken into account the requirements of the institution of society and the labour market concerning speed, levels of forming professional mobility, quality training. Formation of professional mobility in Master training can be productive when it is based on values and consistent with professional competence. In this context, the meaning of Master training should ensure the forming of such features of professional mobility as openness and creativity, resulting in susceptibility to something new and rejection from stereotypes, in relation to the creative professional activities; commitment to the development of new activities; the ability for quick adaptation to the changeable conditions of professional activity; communication.

Educational training programs for Master's degrees in higher education institutions of Ukraine, the USA, the Swiss Confederation are regulated by the legislative documents, regulations, National Qualifications Framework. Among the number of problems of educational and professional programs it is necessary to note common features for different countries - forming identity of specialists, who can solve complex problems and challenges of innovation and research trends in the field of philology.

Educational communities in Ukraine and abroad pay high attention to the problem of the quality of higher education, which largely provides the professional competitiveness in today's job market. The basis of the conceptual foundations of higher education in Ukraine, the USA, Switzerland are tenets defined in UNESCO Declaration "Ensure Inclusive and Equitable Quality Education and Promote Lifelong Learning Opportunities for All" (Swiss Accreditation Council, 2016), including accessibility, openness, technological innovation and interculturality. Swiss Center for Accreditation and Quality Assurance in Higher Education accredits universities, federal technological institutions and their applications. In the USA, actively operate international and national associations of assessment. Ukraine also has made such structures, but the problem of quality at Ukrainian universities has not been sufficiently understood yet. As a result, it occupies 76-th place according to the quality of education among 144 countries in the world ranking of "Global Competitiveness Index" (The World Economic Forum, 2015).

Graduates of Ukrainian Master degress usually work as teachers or instructors, translators or editors. Graduates of American or Swiss universities work as scientific referents; literary critics, scientific editors, translators, researchers at the museum, the library or science teachers, if they mastered appropriate teaching modules. 
In Ukrainian higher education institutions according to the practice experience, it is quite difficult for students to change the education institution even if it works in quite a similar specialty. The reason is differences in the curriculum. An important resource for professional mobility in the analyzed countries is expanding of students' academic mobility (available integrated programs of study and research that caused the possibility of future employment; to enhance the role of universities as academic culture drivers for the development of knowledge and innovatively based economy). In particular, the Swiss Confederation actual educational strategy objectives are employment ( $75 \%$ of the population aged 20-64 years should be employed); scientific research and development (3 \% of EU GDP should be invested in science); education (not less than $40 \%$ of young people aged 30-34 should receive higher education) (Communication from the Commission Europe 2020, 2016).

The analysis of curricula and training programs for Master Philologists' training at Eastern European University, Khmelnytskyi National University, Sumy Pedagogical University, and also Bern, Frieburg, Zurich, Drexel demonstrates the difference in principles of construction. The curriculum of Masters training at domestic universities contains cycles of humanitarian, fundamental, natural sciences, vocational and practical training, which are divided into normative and selective pieces (optional university or according to student's choice). Such a kind of division is not used at American or Swiss universities. Instead, according to A. Zasluzhena (2016), O. Zinovatna (2011), courses are aimed at the training of scientists with defined speciality - linguistics or literature.

Universities offer such special research modules: "The Study of Discourse", "Gender Studies", "Creative Written English", "How to Be a Post-Colonial Critic", "Research Limits of Imagination in the North American Stories" (University of Bern); "Discursive Analysis", "Art of Essay", "Corpus Linguistics", "Introduction to English Literature and Cultural Studies" (University of Freiburg, 2016).

Swiss and American universities Master programs do not include a pedagogical component of teacher training as a teacher of a higher education institution. Such a kind of teachers' training is carried out after the students have acquired Master's degree. Higher education institutions offer Master programs for teaching: Master of Arts in Teaching English; Master of Science in English Language Teaching (Зіноватна, 2011); at Swiss universities - Master of Subject Didactics, which is based on the "Common European Framework of Reference for Languages" (Ніколаєва, 2003), the recommendations of the Committee of Ministers “On Modern Language” (Верховна Рада України, 1998).

The method of increasing professional mobility of future masters is their participation in studying interdisciplinary courses. The English Department of the University of Zurich offers such interdisciplinary subjects as Gender studies, Multilingual Text Analysis, Historical Linguistics, Cultural Analysis. For example, at the University of Bern the course of lectures "The Language in the Speeches" combines language, music and multimedia; Drexel University offers students an interdisciplinary course "Language Studies: Research and Teaching". The curriculum of courses is built on the basis of competence and systemic approaches.

Among the common types and forms of employment for undergraduates, we can note problematic lectures, seminars, workshops, discussions, workshops, problem-oriented research colloquia which aim to actualize modern educational technology of personal development learning, critical thinking. During these activities, students can more critically discuss issues related to future professional activities and jointly perform research projects. Important skills are the group and individual work; the ability to conduct discussions and 
share ideas; presentation of the idea of group work; an individual plan development of the educational process.

The effective form of training and research, professional competence and academic career formation is the participation of students in research "work-shops". On the basis of generalization A. Zasluzhena proposes workshops from Swiss universities under such topics (Заслужена, 2016): "Knowledge and Language Development", "Cognitive Psycholinguistics", "Cognition and Processes of Interpretation", "Bilingualism and Knowledge", "Cognitive Sociolinguistics", "Language and Cognitive Neuroscience", "Experimental Methodology", "Statistical Methodology", etc. These motivational trainings establish a fruitful dialogue between students and philologists in order to unite efforts in the field of forming current professional competencies and activity of individuals, its internal needs in the development of motivation to continuous education and self-education.

At Ukrainian universities such work is carried out, too. In particular, at A. S. Makarenko Sumy Pedagogical University operates a research laboratory "Academic Culture Researcher in the Educational Space", which actively engages students in the interactive discussions, designing of teaching situations, training with materials of qualifying works that are prepared under the school needs of the region.

An effective way of individualization of learning, development of analytical and critical thinking is thesis. In Swiss and American higher education institutions, the educational program provides a choice of writing a Master's thesis, preparation of a research project, which is closely linked to the needs of school facilities, portfolio and etc. At the beginning of the work on thesis, Masters get acquainted with issues of academic integrity and academic culture. It means, in general, the culture of the educational process at university, values, traditions, norms, rules of scientific research, the culture of communication between scientific mentors and students, culture of scientific work and social moral responsibility for the results.

It has been discovered that in the learning process of Swiss, American institutions of higher education are widely integrated new information technologies that contribute to the forming of the necessary ICT competencies. The management of education in a virtual environment of the university during the training of Masters is carried out by various LMS platforms and applications (Moodle, Dokeos, OLAT, ILIAS). Mastering the basics of information and communication technologies and methods of their usage allows students to perform creative tasks more productively and efficiently. At Ukrainian universities the usage of distance learning technologies is not developed enough.

The analysis shows that the educational and scientific training of future philologists at universities is permeated by courses, training of the psychology of interpersonal communication, facilitative professional communication, nonverbal communication. The specifics of Master communicative training is that its language and communicative components become the main factor in the forming of the modern, creative, moral and ethical person, whom every government requires. In this context, the attention to mentoring, tutoring in the training of Masters of philology is highly increasing. It will be discussed in the following publications.

\section{CONCLUSIONS}

Consequently, professional mobility is also an essential indicator of the professional and social maturity of a teacher. The content of Master training should ensure the forming of such kind of features as professional mobility, openness and creativity, that results in susceptibility to new and rejection of stereotypes in relation to the creative professional 
activities; commitment to the development of new activities; the ability to adapt quickly to the changing conditions of professional activity; communicativeness.

The forming of professional mobility of philologists in Master training is productive when it is based on the values of the professional competence. The actualization of the requirements for professional development, creative personality is reflected in both professional and managerial character competence of Master philologists' training. At the analysed universities are developed national standards of Masters' competency training, that is directed at the innovation in professional activities.

The result of the fundamental, research training has to be a specialist of Philology with a high level of social maturity, responsibility for his/her professional and scientific activities, possession of philological and pedagogical knowledge, words and style, culture, reading, compression, editing, translation, building a new high-quality text, culture of communication, willingness to skillfully use the experience gained in various fields of teaching, research, administrative innovative activity.

Rather perspective we consider theoretical analysis of Master philologists' professional training in the context of American guidelines for higher education.

\section{REFERENCES}

1. Bemidji State University. (2016). The Department of English. Retrieved 30.06.2016 from : http://bemidjistate.edu/academics/departments/english/ate.

2. Communication from the Commission Europe 2020. (2010). A Strategy for Smart, Sustainable and Inclusive Growth. Retrieved 30.06.2016 from : http://ec.europa.eu/ eu2020/pdf.

3. Drexel University. (2016). The Department of English. Retrieved 15.11.2016 from : htpp://www.drexel.edu/.

4. Erikson, R. (1992). The Constant Flux. A Study of Class Mobility in Industrial Societies. Oxford : Clareddon, $492 \mathrm{p}$.

5. Ganzenboom, H. B. G., Luijkx, R., Treiman, D. J. (1989). Intergenerational Class Mobility in Comparative Perspective. Greenwich, Conn. : JAIPress, 144 p.

6. Swiss Accreditation Council. (2016). Institutional Accreditation. Retrieved 30.06.2016 from : http://akkreditierungsrat.ch/en/accreditation-switzerland/.

7. University of Bern. (2016). The Department of English. Retrieved 30.06.2016 from : http://www.ens.unibe.ch/research/index_eng.html.

8. University of Freiburg. (2016). Foreign Language Didactics. Retrieved 30.06.2016 from : http://studies.unifr.ch/en/master /multi /foreignlanguagedidactics.

9. University of Zurich. (2012). English Seminar. Academic Report. Retrieved 30.06.2016 from : http:/www.es.uzh.ch/dam/jcr:00000000-087b-d64d-fffffffa508283b/ES AkaBer_12.pdf.

10. The UNESCO. (2015). Incheon Declaration "Education 2030: Towards Inclusive and Equitable Quality Education and Lifelong Learning for All”. World Education Forum 2015 (Incheon, Republic of Korea, 19 - 22 May, 2015). Paris : UNESCO Publishing, 76 p.

11. The World Economic Forum. (2015). The Global Competitiveness Report 20142015. Retrieved 30.06.2016 from : http:/www.weforum.org/issues/global-competitiveness/.

12. Верховна Рада України [The Verkhovna Rada of Ukraine]. (1998). Рекомендація N R (98) 6 Комітету міністрів Ради Свропи «Про сучасні мови» [Тhе Recommendation N R (98) 6 of the Committee of Ministers "About the Modern 
Languages"]. Retrieved 30.06.2016 from : http://zakon3.rada.gov.ua/laws/show/994_725 (in Ukrainian).

13. Верховна Рада України [The Verkhovna Rada of Ukraine]. (2014). Закон Украӥни "Про вищу освіту" [The Law of Ukraine "On Higher Education"]. Retrieved 30.06.2016 from : http://zakon4.rada.gov.ua/laws/show/1556-18 (in Ukrainian).

14. Заслужена, А. А (2016). Підготовка магістрів з англійськоӥ мови та літератури в університетах Швейцарської Конфедерації [Training of Masters in English language and Literature at the Universities of the Swiss Confederation]. Thesis for $\mathrm{PhD}$. Сумський державний педагогічний університет імені А. C. Макаренка, 323 p. (in Ukrainian).

15. Зіноватна, О. М. (2011). Модернізація філологічної освіти магістерського рівня Украӥни: адаптаиія американського досвіду [The Modernization of Philological Education at Master Level in Ukraine: the Adaptation of American Experience]. Черкаси, 76 p. (in Ukrainian).

16. Національна академія педагогічних наук України [The National Academy of Pedagogical Sciences of Ukraine]. (2016). Національна доповіды про стан $i$ перспективи розвитку освіти в Украӥні [The National Report on the Status and Prospects of Education Development in Ukraine]. К. : Педагогічна думка, 234 р. (in Ukrainian).

17. Національна академія педагогічних наук України [The National Academy of Pedagogical Science]. (2016). Стратегія розвитку Національної академії педагогічних наук Украйни на 2016-2022 роки [The Strategy of the Development of National Academy of Pedagogical Sciences of Ukraine in 2016-2022]. Retrieved 30.06.2016 from : naps.gov.ua/ua/press/announcements/942/ (in Ukrainian).

18. Нечволод, Л. I (2007). Сучасний словник іншомовних слів [Modern Dictionary of Foreign Words]. Х. : ТОРСІНГ ПЛЮС, 768 c. (in Ukrainian).

19. Ничкало, Н. Г. (2007). Професійна освіта і навчання: проблеми взаємозв'язку з ринком праці [The Professional Education and Training: the Problems of the Interrelation with Labour Market]. In : Вайс, Ю., Ничкало, Н., Сімак, А. Формування широкої кваліфікації робітників : вклад ПТО у розвиток трудового потенціалу ХХІ століття : зб. матеріалів, підгот. у рамках реалізачї укр.-нім. проекту "Підтримка реформи професійно-технічної освіти в Украйні" [Forming a Wide Qualification of Workers: the Input of Vocational Education in the Development of the Labour Force in the 21st Century: the Collection of Scientific Materials Prepared in the Framework of Ukrainian-German Project "Maintaining the Reforming of Vocational Education in Ukraine"]. Ніжин, pp. 134-138 (in Ukrainian).

20. Ніколаєва, С. Ю. (2003). Загальноєвропейські Рекомендачії з мовної освіти: вивчення, викладання, очінювання [Common European Framework of Reference for Languages: Learning, Teaching, Assessment]. К. : Ленвіт, 273 p. (in Ukrainian).

21. Ожегов, С. И., Шведова, Н. Ю. (1999). Толковый словарь русского языка [Explanatory Dictionary of the Russian language]. M. : Азбуковник, 944 p. (in Russian).

22. Парсонс, Т. О (2000). О структуре социального действия [About the Structure of Social Action]. М. : Академ. Проект, 880 p. (in Russian).

23. Сорокин, П. (2008). Система сочиологии [The System of Sociology]. M. : Астрель, 1008 p. (in Russian).

24. Сушенцева, Л. Л. (2011). Формування професійної мобільності майбутніх кваліфікованих робітників у професійно-технічних закладах: теорія і практика [Тhе Forming of Future Skilled Workers' Professional Mobility in Vocational Schools: Theory and Practice]. Кривий Ріг : Видавничий дім, 439 р. (in Ukrainian). 